\title{
Sobre a Possibilidade da Metafísica em Aristóteles a partir da Primeira Aporia

\author{
do Livro Beta
}

\author{
Marina dos Santos ${ }^{1}$
}

\author{
À memória de Balthazar Barbosa Filho
}

The present paper aims to discuss the role of the Book Beta in Aristotle's Metaphysics. On the basis of an alleged fragmentation of this work, the Metaphysics lacks a unified investigative project. Accordingly, it would be impossible to ensure a coherent argumentative chain among the issues raised in book Beta, whose resolution is necessary for the possibility of establishing this new scientific corpus. On the other hand, this paper aims to present an approach to the Book Beta whereby the Aristotelian concern in offering a methodological procedure capable of ensuring a priori the possibility of the science of Metaphysics is highlighted. This interpretation is justified because the very concept of an absolutely first science to be consistent requires the resolution of certain problems in Book Beta. As a result, in the supposition that the science of Metaphysics in Aristotle is a priori possible, we claim the Philosopher does have a method which is strong enough to meet the scientificity requirements for a single unified science that deals with the absolutely universal principles and causes of being.

O livro Beta da Metaphysica de Aristóteles ${ }^{2}$ teve sua importância bastante circunscrita e reduzida, sobretudo a partir do diagnóstico da fragmentação geral dessa obra oferecido por

\footnotetext{
${ }^{1} \mathrm{O}$ presente artigo consiste no concerto de extratos das pesquisas realizadas em minha dissertação de mestrado (Dos Santos, Marina. As aporias do Livro Beta da Metafísica de Aristóteles. Dissertação (mestrado) - Universidade Federal do Rio Grande do Sul. Instituto de Filosofia e Ciências Humanas. Programa de Pós-Graduação em Filosofia, Porto Alegre, BR-RS, 2006), e tese de doutorado (Santos, Marina. A unidade da Metafísica de Aristóteles a partir das aporias do Livro Beta. Tese (doutorado) Universidade Federal do Rio Grande do Sul. Instituto de Filosofia e Ciências Humanas. Programa de Pós-Graduação em Filosofia, Porto Alegre, BR-RS, 2011), as quais contaram com bolsas de estudo financiadas pelo CNPq e Capes.

${ }^{2}$ A citação das passagens da Metaphysica e de quaisquer outras obras de Aristóteles será sempre feita segundo a numeração e divisão em colunas ' $a$ ' e 'b' da edição de Immanuel Bekker. As traduções das passagens da Metaphysica citadas em língua portuguesa são sempre de minha responsabilidade e foram realizadas a partir do cotejamento do texto grego com as traduções de Yebra (Aristóteles, 1998), Ross (Aristotle, vol. ii, 1995, pp.1552-1728) e Tricot (Aristote, 2003). Alexandre de Afrodísia e Tomás de Aquino serão, respectivamente, citados segundo a numeração da edição do texto grego de Michael Hayduck e segundo a divisão e numeração do texto latino em parágrafos da edição de $\mathrm{M}$. R. Cathala \& R. M. Spiazzi.
} 
Werner Jaeger. ${ }^{3}$ Tal diagnóstico tornou impossível considerar a Metaphysica como uma obra possuidora de um projeto investigativo (e literário) unitário, bem como o estabelecimento de um vínculo argumentativo seguro entre os problemas que o livro Beta suscita e de cuja resolução dependeria a possibilidade da constituição desse novo corpus científico. O objetivo do presente artigo consiste numa tentativa de resgate da importância do livro Beta como marca da preocupação aristotélica em oferecer um procedimento metodológico capaz de tornar tal ciência possível a priori na medida em que a resolução de certos problemas parece necessária para que o conceito mesmo de uma ciência absolutamente primeira seja tornado consistente. Nessa medida, dizer que a metafísica é possível a priori, em Aristóteles, consistirá em mostrar que o filósofo dispõe de um método capaz de apontar como a ciência buscada ao longo dos quatorze livros, que nos chegaram reunidos sob o nome de Metaphysica, pode preencher os requisitos de cientificidade de uma única e mesma ciência que trata dos princípios e causas absolutamente universais do ser.

O caráter preliminar do livro Beta em relação ao restante da Metaphysica é apontado, por Aristóteles, como o elemento que torna possível a compreensão e resolução dos problemas que a ciência buscada deve investigar. Nesse sentido, Aristóteles crê que os problemas, assim como os nós, não podem ser desatados ou resolvidos quando ignorados: o investigador que desconhece a natureza do seu problema não poderá alcançar a sua solução, pois não sabe como avançar em direção a tal fim, dado que desconhece completamente o caminho que deveria seguir para alcançá-lo, e, mesmo que a solução para seu problema, eventualmente, se apresentasse a tal investigador, ele não saberia reconhecê-la. Assim sendo, a diaporemática parece facilitar o caminho até a filosofia primeira na medida em que o investigador que dispõe do conhecimento das razões que sustentam cada uma das posições em litígio, as quais amparam teses divergentes entre si, e das consequências envolvidas por cada uma dessas posições, encontra-se em melhores condições de decidir, não apenas a favor de um lado ou de outro, mas, ao pesar as razões que justificam cada uma das posições divergentes, poderá encontrar uma solução ainda melhor que coadune o que há de verdadeiro e exclua o que há de falso nas diferentes posições. Desse modo, o investigador será capaz de formular uma solução que supere as dificuldades e contradições que tais teses apresentam, sendo-lhe possível resolver definitivamente a aporia e estabelecer a verdade sobre os problemas em que a ciência buscada encontra-se enredada.

\footnotetext{
${ }^{3}$ Jaeger, W. Aristóteles: bases para la historia de su desarrollo intelectual. (México, Fondo de cultura económica, 1995).
} 


\section{Da discussão da primeira aporia em Metaphysica Beta}

A primeira aporia de Beta é enunciada em B 1 995b4-6: “A primeira dificuldade se refere ao problema que já suscitamos na introdução: se corresponde a uma só ou a várias ciências investigar as causas".

\section{A discussão da primeira aporia encontra-se em B 2 996a18-b26:}

Examinemos, em primeiro lugar, a questão que suscitamos primeiro, se concerne a uma ou a várias ciências contemplar todos os gêneros de causa. Como pode ser próprio a uma só ciência conhecer os princípios, não sendo esses contrários entre si? Além disso, em muitos dos seres não estão presentes todos os princípios. Como, então, pode ser possível que haja nas coisas imóveis um princípio do movimento ou a natureza do bem, se tudo o que é, por sua própria natureza, um bem é um fim e, portanto, uma causa, dado que em vista dele se fazem e existem as demais coisas, e, uma vez que "aquilo em vista do que" se faz algo é o fim de alguma ação e que todas as ações se executam com movimento? Por conseguinte, não se pode admitir a existência desse princípio nas coisas imóveis nem que haja algum bem em si. Por isso, nas matemáticas nada se demonstra através dessas causas nem há demonstração porque algo é melhor ou pior e, de fato, ninguém menciona qualquer coisa desse tipo. Por essa razão, alguns sofistas, como Aristipo, depreciam as matemáticas. Pois diziam que nas demais artes, inclusive nas servis, como a do carpinteiro ou a do sapateiro, tudo se explica dizendo se algo é melhor ou pior, enquanto que as matemáticas em nada se ocupam do bom e do mau.

Mas, se são várias as ciências das causas e se cada uma trata de um princípio distinto, qual dessas deverá ser dita a ciência que buscamos ou a quem, dentre aqueles que as possuem, deveremos considerar como o maior conhecedor do tema que nos ocupa? Pois é possível que se apresentem todos os tipos de causas numa mesma coisa; por exemplo, em uma casa, a causa de onde provém o movimento é a arte e o construtor, aquilo em vista do que se faz essa obra, a matéria, terra e pedra, e a forma é a definição. Assim, pois, tendo em vista o que fora exposto para determinar a qual dessas ciências deve-se chamar sabedoria, é razoável proclamar como tal a cada uma delas. Pois, na medida em que ela é a mais digna de mandar e de dirigir e as outras ciências, enquanto servas, não lhe devem contradizer, a ciência do bem e do fim é da natureza da sabedoria (dado que as outras coisas são em vista do fim e do bem). Mas, na medida em que foi definida como ciência das primeiras causas e do maximamente cognoscível, seria sabedoria a ciência da substância. Pois, uma vez que se pode saber a natureza de uma coisa de vários modos, dizemos que sabe mais dela aquele que conhece o que é a coisa pelas características que ela tem do que aquele que conhece o que a coisa é pelas características que ela não tem e, dentre aqueles que conhecem o que a coisa é pelas suas características, aquele que sabe o que a coisa é sabe mais do que aquele que conhece sua quantidade ou qualidade ou o que, por natureza, ela pode fazer ou sofrer. Além disso, em todos os outros casos, inclusive em relação àquelas coisas de que há demonstração, nós só acreditamos que há conhecimento de cada coisa quando nós conhecemos o que ela é (por exemplo, o que é construir um quadrado igual a um retângulo? Fazer uma média; e, assim, nas demais coisas); e nós conhecemos sobre as gerações e as ações e sobre toda mudança quando conhecemos o princípio da mudança. Mas isso é diferente e oposto ao fim; portanto, parece pertencer a distintas ciências investigar a cada uma dessas causas.

Aristóteles discute a primeira aporia introduzindo duas teses opostas sobre a questão se pode haver uma única ciência que trate de todos os tipos de causa. A primeira parte da discussão consiste na apresentação de argumentos contra a tese que há uma ciência de todas as causas, a saber: i) coisas especificamente diferentes são objeto de uma mesma ciência somente se forem contrárias entre si. Ora, as causas são especificamente diferentes, mas não são contrárias entre si; logo, não pertencem a uma mesma ciência; ii) nem todas as coisas 
possuem todos os tipos de causa, como ocorre, por exemplo, com as substâncias imóveis e os objetos matemáticos (os quais não possuem causa material, eficiente nem final). Isso implica que certas ciências possuam conhecimento sobre algumas causas e não sobre outras, conforme os tipos de causalidade pertencentes a seus respectivos objetos. Por isso, não pode haver uma ciência que trate de todas as causas. A segunda parte da discussão consiste em apresentar argumentos em prol da tese que deve haver uma única ciência de todas as causas, a saber: a ciência buscada não pode ser identificada a nenhuma ciência que se ocupe separadamente de alguma(s) da(s) causa(s), pois seria difícil decidir qual, dentre as ciências que se limitam desse modo, deveria ser considerada filosofia primeira.

O primeiro argumento contra uma ciência de todas as causas alega que só pode haver uma ciência una acerca daquelas coisas que, diferindo em espécie, são contrárias entre si. As causas diferem segundo a espécie, mas não são contrárias, por isso não podem estar sob o escopo de uma mesma ciência. Aristóteles afirma que a ciência trata dos contrários em função de todo conhecimento científico, teórico ou prático, e artístico engendrar-se a partir de conceitos que o intelecto humano forja acerca das coisas que lhe servem de objeto de investigação ou produção. O conceito, enquanto revelador da essência do objeto conhecido, é portador dos contrários em função de explicar tanto o objeto conhecido quanto a sua negação ou privação. Contudo, é causa explicativa em sentido primeiro do objeto e em sentido secundário ou derivado da privação do objeto. Assim, por exemplo, a ciência que trata da temperatura dos corpos tratará em sentido primeiro do quente e subsequentemente do frio, o qual é ausência ou privação do calor. Do mesmo modo, a medicina é conhecedora e produtora em sentido primeiro da saúde e secundariamente da doença.

Segundo Alexandre de Afrodísia (180,34 - 187,13), o argumento supracitado é válido (se as premissas fossem verdadeiras, a conclusão seguir-se-ia necessariamente). Porém, ele parte de uma premissa falsa, a saber, coisas de diferentes espécies pertencem a uma mesma ciência se e somente se são contrárias entre si. Segundo Alexandre, é verdade que contrários pertencem à mesma ciência, mas sua contrapositiva é que coisas que não pertencem à mesma ciência não são contrárias, o que, por sua vez, não equivale a dizer (conforme a falsa premissa) que somente coisas contrárias pertençam à mesma ciência. Alexandre de Afrodísia ressalta que, do fato de contrários pertencerem à mesma ciência, não se segue, sem mais, que somente contrários pertençam à mesma ciência. Isso pode ser ratificado por um exemplo de coisas que não são contrárias entre si e que, no entanto, pertencem à mesma ciência: os objetos da geometria.

Tomás de Aquino, de sua parte, afirma (§370) que da implicação, "se coisas são 
contrárias entre si, então elas pertencem à mesma ciência", não se segue, conforme o que a conclusão do inválido argumento supracitado quer estabelecer, que, se coisas não forem contrárias entre si (negação do antecedente), então elas não pertencem à mesma ciência, pois da negação do antecedente não se segue que tais coisas não pertençam à mesma ciência nem que pertençam.

O segundo argumento contra uma única ciência de todas as causas afirma que os tipos de causa que devem ser tratados por certa ciência dependem dos tipos de causalidade presentes nos objetos que são próprios a ela e, dado que nem todas as coisas possuem todos os tipos de causa, como, por exemplo, as substâncias não sensíveis e os objetos da matemática não possuem causa eficiente nem final, então não pode haver uma ciência de todas as causas. Portanto, segundo esse argumento que visa a estabelecer a impossibilidade de haver uma única ciência de todas as causas, se há objetos próprios a uma ciência e se tais objetos não possuem todos os tipos de causalidade, então cada ciência deveria tratar das causas pertencentes aos objetos que lhes são próprios.

Tomás de Aquino (§§ 372-375) afirma que esse segundo argumento tem como premissa maior uma proposição já provada pelo argumento anterior, a saber, é evidente, a partir do caso dos contrários, que coisas especificamente diferentes são tratadas pela mesma ciência. A premissa menor é que nem toda ciência que trata de uma das causas trata de todas. Disso conclui-se que o estudo de todas as causas não pertence a uma única ciência. A premissa menor, segundo o Aquinate, é provada da seguinte maneira: diferentes ciências tratam de diferentes seres e há muitos seres nos quais nem todas as causas estão presentes. Isso é evidente, primeiramente, no caso daquelas coisas que não possuem princípio de movimento, a causa eficiente, como, por exemplo, os números e aquelas coisas postuladas pelos platônicos, as formas separadas. Portanto, se alguma ciência considera essas coisas, então ela não tratará da causa eficiente. Em segundo lugar, Aristóteles prova que isso também é verdadeiro em relação à causa final, a qual consiste no bem da coisa, pois não parece que nas coisas imóveis, tais como concebidas pelos platônicos, esteja presente um fim que lhes é externo e ao qual tendem, ou seja, elas não são um meio útil para chegar-se à outra coisa, visto que tais coisas são em si mesmas um bem e, em razão de suas próprias naturezas, um fim. Tomás de Aquino dá como exemplo de coisas que não são um bem em si mesmas, mas apenas úteis para alcançar um bem em si, o remédio amargo, o qual é apenas meio para alcançar a saúde. Segundo o Aquinate, Aristóteles apresenta outra razão que deve ser levada em conta para corroborar a tese que as coisas imóveis não possuem causa final, a saber, um outro sentido em que "bem", o fim da ação, a qual parece sempre envolver movimento, é dito. 
Em função das acepções em que a causa final ou o bem é dito, parece não ser possível que as coisas imóveis, tais como as concebera Platão (isto é, subsistentes por si mesmas e separadas da matéria), possam ser consideradas bens em si. O Estagirita torna clara tal afirmação, segundo o comentário de Tomás de Aquino, mediante o seguinte exemplo: nas ciências matemáticas, as quais tratam de seus objetos enquanto separados da matéria e imóveis, nada é provado a partir da causa final, ao contrário do que ocorre na ciência da natureza, cujos objetos, as coisas móveis, têm um de seus atributos essenciais, o movimento, provado mediante o apelo à causa final, ao bem que pertence respectivamente a cada espécie das coisas que povoam a natureza. O Aquinate exemplifica isso dizendo que nós podemos dar como razão de um homem ter mãos o fato que, com elas, ele é mais capaz de executar as coisas que o intelecto concebe. É evidente que nenhuma explicação desse tipo pode ser dada na matemática, pois sequer há sentido em dizer que um atributo de determinado objeto matemático o torna capaz de ser melhor quando tal objeto o possui e pior quando não o possui. Em função disso, não faz sentido dizer que o ângulo no semicírculo é reto porque é melhor para o semicírculo que o ângulo seja reto do que agudo ou obtuso. Pelo fato de não haver e não poder haver nas matemáticas qualquer menção à causa final, alguns sofistas, tal como Aristipo, depreciam-nas, pois eles acreditam que até mesmo as artes mais servis, como a do carpinteiro ou a do sapateiro, baseiam suas explicações naquilo que é melhor ou pior em relação a seus objetos, enquanto a supostamente mais exata entre as ciências não faz menção ao bem e ao mal.

Toda a tese que não pode haver uma única ciência de todas as causas em função de nem todos os objetos possuírem todos os tipos de causalidade (conforme expõe Alexandre de Afrodísia em 183,1-8) desenvolve-se em torno de uma falácia, pois, do fato de nem todas as causas pertencerem a todos os objetos de ciência, não se segue que não pertença a uma única ciência o conhecimento de todas elas. Poder-se-ia, pois, usar esse tipo de raciocínio para provar que, no caso de todas as causas pertencerem aos objetos de uma mesma ciência, então a ela caberá o estudo de todas as causas, o que justamente contradiz o que o argumento falacioso queria mostrar. Um exemplo de ciência cujos objetos possuem todas as causas é a filosofia da natureza.

A segunda parte da discussão da aporia, iniciada em 996b1, começa a partir da consideração da tese positiva da posição analisada acima, isto é, que diferentes tipos de causalidade devem ser tratados por diferentes ciências. A defesa de tal tese engendra as seguintes questões: como saber qual das ciências que tratam separadamente de cada uma das causas é a ciência buscada? Há um tipo de causalidade que pode ser considerado o mais 
importante na produção de conhecimento científico? A ciência que trata desse tipo mais importante de causalidade pode ser identificada à ciência buscada?

No que concerne à questão de como saber qual, dentre as ciências que tratam separadamente de cada uma das causas, é a ciência buscada, Aristóteles a discute tendo em vista as considerações, realizadas em A 3-9, acerca da natureza dos diferentes tipos de causalidade. Isso significa que se deve procurar a ciência buscada entre aquelas ciências que tratam ou da causa formal ou da final ou da eficiente, ficando de fora a causa material, dado que a matéria é um dos elementos constitutivos da natureza dos seres compostos, o qual é princípio de indeterminação e potencialidade e que só vem a ser algo determinado quando do concurso do princípio de atualidade e determinação do composto hilemórfico, a forma. Dessa maneira, a matéria não é nada de determinado por si mesma, mas somente enquanto mantém relação com a forma. Nota-se que a exclusão da matéria como candidata à causa tratada pela filosofia primeira já indica uma tese que perpassa toda a investigação que Aristóteles opera na Metaphysica, a saber, que ser é, em sentido principal, ser determinado. Tal tese faz-se presente na eleição da substância como o modo principal de ser e na defesa do princípio de não contradição em $\Gamma$, a eleição da forma como princípio de substancialidade do composto em mais alto grau em $Z$, a prioridade do ato sobre a potência em $\Theta$ e a caracterização do primeiro motor como forma e atualidade puras em $\Lambda$.

A seguir, Aristóteles passa a analisar cada uma das ciências que tratam das três causas supracitadas, começando pela final, a qual parece ser mais merecedora do nome de filosofia primeira, pois exibe suas características, a saber, é primeira no que diz respeito à dignidade $\mathrm{e}$ a uma maior influência sobre as demais ciências na medida em que todas as coisas existem com vistas a um fim. Desse modo, a ciência que trata da causa final está mais apta a ser chamada de filosofia primeira. As artes concernentes ao fim de um artefato são mais importantes do que as outras artes que tratam das demais causas, por exemplo, a arte da navegação é mais nobre do que a da engenharia naval, pois navegar é o fim em vista do qual o navio é construído.

Relativamente à causa formal, Aristóteles argumenta que, tendo em vista que à sabedoria concerne à investigação das causas primeiras e do que é mais cognoscível e mais exato em si mesmo, parece dever ser a substância o objeto de estudo da ciência buscada. Tal afirmação é feita em razão de o ser primeiro, a substância, ser o único modo de ser, dentre os modos categoriais, que é por si em contraposição ao ser por outro, os acidentes, que só possuem ser de modo dependente ao ser da substância. Dessa maneira, o ser primeiro, a substância, é, por si mesmo, mais determinado e cognoscível do que os acidentes. O 
conhecimento científico demonstrativo tem início a partir das definições dos objetos investigados, as quais são expressão lógica da quididade deles, aquilo que revela o que é ser para o objeto definido. É nesse sentido que se responde à pergunta "o que é o fazer quadrado?" dizendo que é "achar a média". Tomás de Aquino explica esse exemplo, no §380:

Fazer quadrada uma superfície de lados equidistantes que não é quadrada, mas que nós dizemos ser quadrada quando encontramos, ao analisar suas linhas, um quadrado igual a ela. Toda superfície retangular de lados equidistantes é formada por duas linhas as quais contêm um ângulo reto. Dado que sua superfície total é simplesmente o produto da multiplicação de uma das linhas pela outra, então nós encontramos um quadrado igual a essa superfície quando nós encontramos uma linha que é a média proporcional entre aquelas. Por exemplo, se a linha A é para a linha B tal como a linha B é para a linha $\mathrm{C}$, o quadrado de linha $\mathrm{B}$ é igual à superfície contida por $\mathrm{C}$ e $\mathrm{A}$, como é provado no livro $\mathrm{VI}$ dos Elementos de Euclides.

Alexandre de Afrodísia comenta essa mesma passagem de Aristóteles, em 185,32 186,1, dizendo que conhecemos o que é a quadratura do retângulo quando encontramos a média proporcional em função do quadrado estar fundado sobre a linha média, a qual é igual em área ao retângulo. O Aquinate prossegue comentando que isso torna-se evidente no caso dos números, pois 6 é a média proporcional entre 9 e 4, pois 9 está para 6 na razão de $1 \frac{1}{1} 2$ para 1 e do mesmo modo 6 está para 4. Já o quadrado de 6 é 36, o que também resulta da multiplicação de 4 por 9 . E de modo similar ocorre com todas as outras coisas.

Aristóteles apresenta ainda um argumento em prol da causa eficiente, afirmando que através dela nós conhecemos o processo de geração e ação de tudo o que muda, sendo ela nada mais do que a atualidade de algo móvel produzida por um motor. Dessa maneira, a tese que defende uma ciência diversa para cada tipo de causalidade torna-se insustentável, visto que as causas formal, final e eficiente, possuem igualmente dignidade para receber o nome de filosofia primeira. A tese da multiplicidade de ciências gera também o absurdo que causas de um mesmo objeto, no qual esteja presente mais de um tipo de causalidade, sejam tratadas por ciências diferentes; Assim, por exemplo, cada uma das substâncias naturais, as quais possuem os quatro tipos de causas, seriam objetos de investigação de quatro ciências diferentes, com o agravante de ser problemático decidir, dentre três delas, qual revela em mais alto grau o que é ser para o objeto investigado (com exceção daquela que trataria da causa material).

$\mathrm{Na}$ medida em que se torna difícil sustentar que existe uma ciência diferente para cada tipo de causa, a tese que há uma mesma ciência de todas elas tornar-se-á plausível mediante os mesmos argumentos que tornaram problemática a tese da multiplicidade. Dessa maneira, a tese da unidade firma-se pelo fato que cada uma das ciências que tratam separadamente das causas (exceto a material) possui legitimidade para serem ditas ciência em mais alto grau. Dessa forma, parece que a filosofia primeira deve estudar todos os tipos de causalidade, pois, 
mesmo que ela trate de algum objeto que não possua todas as causas, ela deve conhecer todos os tipos de causalidade possíveis em função de ser ciência em mais alto grau, podendo, dessa forma, dar conta das causalidades presentes em todas as coisas.

Desse modo, Aristóteles parece deixar uma indicação ao leitor sobre qual resposta poderia ser dada para resolver os problemas, mesmo que a função da discussão de cada aporia em B seja somente problematizar ao extremo cada uma das questões que devem ser respondidas para que a possibilidade da ciência buscada seja estabelecida (no caso das aporias chamadas fundamentais) e para determinar a verdade sobre o conteúdo das teses (no caso das demais aporias) que formarão o corpo dessa ciência.

\section{Da resposta à primeira aporia ao longo da Metaphysica}

A primeira aporia parece ser primeira não só na ordem do texto, mas também em razão dela deixar em suspenso que a ciência buscada detenha a característica mais fundamental de todo e qualquer conhecimento científico, a saber, ser um conhecimento das causas. Se não for possível dar uma resposta positiva a ela, mostrando que deve haver uma única ciência que trate de todos os tipos de causalidade presentes na realidade, então a ciência buscada é impossível a priori no sentido em que ela sequer é capaz de possuir as notas características que constituem a própria definição de ciência. Nesse sentido, a caracterização da ciência buscada na Metaphysica parece estar em consonância com a definição de ciência de Analytica Posteriora I 2 71b9-16: "Julgamos conhecer cada coisa, de modo absoluto e não, à maneira sofística, quando julgamos conhecer a causa pela qual a coisa é, que ela é a sua causa e que não pode essa coisa ser de outra maneira". ${ }^{4}$ Assim, se a filosofia primeira não puder preencher os requisitos da cientificidade, a saber, constituir um discurso unitário revelador das causas e princípios presentes na realidade, então ela não poderá ser ciência nem, portanto, ciência primeira.

Tendo isso em vista, parece haver uma assimetria entre a perspectiva etiológica, a qual é posta em xeque pela primeira aporia, e as demais perspectivas (ontologia, ousiologia e teologia) que reside no fato que 'ser ciência das causas' não é uma característica capaz de diferenciar a ciência primeira das ciências particulares, pois todas elas são ciência das causas. É tão somente na medida em que for determinado o objeto em relação ao qual a ciência buscada investiga as causas e qual o tipo de foco de que ela se vale nessa investigação que se

\footnotetext{
${ }^{4}$ Conforme tradução de Pereira, Oswaldo Porchat. Ciência e Dialética em Aristóteles (Editora UNESP 2000), p. 35.
} 
poderá determinar e preencher, por assim dizer, o seu caráter etiológico. É na determinação do objeto material (o ser) e do objeto formal ${ }^{5}$ (enquanto ser) realizada quando do estabelecimento das perspectivas ontológica, ousiológica e teológica que a ciência buscada tornará claro o que a distingue das "etiologias" características das ciências particulares.

Mesmo que o caráter etiológico não seja capaz de determinar, por si só, a natureza da ciência buscada, ele parece ser a base sem a qual o conceito de ciência primeira não poderia ser constituído. Nesse sentido, parece que, se a dimensão etiológica não for estabelecida, então essa impossibilidade da ciência buscada é imediatamente transferida às demais dimensões, as quais são diferentes perspectivas de uma única e mesma ciência, na medida em que determinam, sob diferentes aspectos, os princípios e causas do real. Se, assim for, a relação de implicação existente entre a dimensão etiológica e as demais parece ser recíproca, pois, ao mesmo tempo em que é possível afirmar que se ela não preencher os requisitos de cientificidade sozinha, então a impossibilidade da ciência primeira é imediatamente transferida às demais dimensões, a dimensão etiológica só ganha sentido completo quando for determinado o objeto dessa ciência das causas absolutamente primeiras, isto é, quando ficar acertado que ela investiga as causas absolutamente primeiras do ser enquanto ser, da substância e da substância absolutamente primeira. Assim, a impossibilidade do estabelecimento da dimensão etiológica torna o estabelecimento das demais dimensões impossível, porém, ela só ganha inteligibilidade através das qualificações ou determinações que as demais dimensões exercem sobre ela. Ao longo da Metaphysica, a ciência buscada vai desdobrando-se primeiramente como ciência das primeiras causas (etiologia) e princípios do ser enquanto ser (ontologia). A seguir, a principal forma do ser passa a ser identificada à substância, na medida em que ela se revela o modo principal do ser, o ser primeiro, e é dessa maneira que a ciência buscada passa a ser a ciência das primeiras causas (etiologia) da substância (ousiologia). O último desdobramento dessa ciência culmina no âmbito teológico na medida em que torna necessário, aos olhos de Aristóteles, o estabelecimento de um ser absolutamente primeiro, o primeiro motor imóvel em relação ao qual Aristóteles procurará elucidar não só as causas que determinam sua natureza, mas de que modo ele é causa da realidade, a saber, enquanto ele é causa final da eternidade do movimento do universo. Tal

\footnotetext{
${ }^{5}$ Barnes explicita o sentido da expressão "ser enquanto ser" traçando a distinção entre escopo ou o domínio (as coisas que existem) e foco (enquanto existentes) da ontologia indicando que a expressão "enquanto ente" qualifica o modo como a investigação acerca das coisas existentes vai se dar na medida em que essa expressão qualifica o aspecto das coisas existentes que será investigado pela ontologia. Ver Barnes, J. "Metafísica". In Barnes, J. (ed.): Aristóteles. (São Paulo, Ideias e Letras, 2009), pp. 106-110.
} 
percurso deverá ser acompanhado tendo como foco a afirmação aristotélica que, em todos os argumentos que conduzem ao estabelecimento de cada uma das perspectivas da ciência primeira, o que se busca são as causas e os princípios sejam eles pertencentes ao ser enquanto ser, à substância ou à substância absolutamente primeira.

Tal alternativa de interpretação pretende afastar, assim, uma leitura que não vê qualquer resposta explícita a tal aporia ${ }^{6}$ ou limite tal resposta a uma única perspectiva em que a ciência buscada se desdobra. ${ }^{7}$ O livro A apresenta a dimensão etiológica da filosofia primeira e costuma ser dividido em dois momentos: A 1-2 apresenta uma parte do projeto da Metaphysica (o qual é completado em E 1) procurando fazer uma primeira determinação do tipo de causalidade próprio à investigação da ciência primeira e A 3-10 apresenta uma doutrina da causalidade que visa a mostrar que os tipos de causa presentes na realidade são quatro (material, formal, eficiente e final) a partir da consideração dos erros e acertos dos predecessores sobre tal tema. É na primeira parte de A (1-2) que parece ser possível encontrar o primeiro passo da argumentação que responde pelo tipo de causalidade próprio à investigação metafísica. Por essa razão, buscar-se-á nesses dois capítulos a primeira parte da resposta à primeira aporia e deixar-se-á de lado aqui a análise de A 3-10, a qual visa a determinar quais os tipos de causalidade que preenchem o conceito de 'causa' a partir de uma discussão sobre a doutrina dos predecessores.

\footnotetext{
${ }^{6}$ À primeira vista, Tomás de Aquino, no início do $\$ 384$, mostra-se pouco crédulo em relação à possibilidade da identificação de uma resposta explícita à primeira aporia. No entanto, o Aquinate parece ser o único comentador que oferece subsídios suficientes para uma resposta que perpasse todas as outras três perspectivas (além da etiologia) em que a ciência buscada se desdobra. Nos $\S \S 384-386$, ele afirma que parece ser possível estabelecer uma resposta a tal aporia a partir de argumentos localizados em diferentes lugares da Metaphysica. Nesse sentido, o Aquinate apresenta uma razão (que só será anunciada em $\Gamma$ e provada em Z) para sustentar a existência de uma mesma ciência que trata de todos os tipos de causalidade: mesmo que as causas, diferindo em espécie, não sejam contrárias entre si, elas podem ser tratadas pela mesma ciência na medida em que pode ser identificado, dentre os quatro tipos de causalidade, um tipo que serve de elemento unificador e primaz entre eles, a causa formal. Essa razão mostrar-se-á boa em função da substância ser identificada ao ser primeiro, isto é, ao principal modo de ser dentre as categorias em que o ser sensível encontra-se disperso, o qual é capaz de servir de elemento unificador na medida em que os demais modos categoremáticos possuem existência relativamente a ele. A forma, por sua vez, responderá, em $Z$, por aquilo que é causa da substancialidade do ser sensível primeiro em mais alto grau. Tomás de Aquino também sugere a perspectiva etiológica se espraia também pela argumentação que estabelece as causas e princípios de substancialidade das substâncias imóveis bem como o tipo de causalidade que eles exercem sobre as substâncias móveis (ver especialmente o §385).

${ }^{7}$ Tal como o fazem Madigan in Aristotle. Metaphysics - Books B and K 1-2 (Clarendon Aristotle series, Oxford, Claredon Press, 1999), pp. 39-40, e Crubelier in "Aporiai 1-2", In: Crubelier, M. \& Laks, A. (ed.), Aristotle's Metaphysics Beta. Symposium Aristotelicum (Oxford University Press, 2009), pp. 61-62, os quais limitam, respectivamente, a resposta à argumentação da componente ontológica (Г 1 1003a26-32, 2 1003a33-b19) e da componente teológica $(\Lambda$ 7).
} 


\section{1. A base fundante da resposta à primeira aporia: a caracterização da ciência buscada} como ciência dos princípios e causas absolutamente primeiros em Metaphysica A 1-2

O objetivo geral de Metaphysica A 1-2 é apresentar genericamente a necessidade da investigação acerca de uma nova ciência, a qual ele chama de a ciência buscada, através de uma argumentação de base teleológica. A função própria do homem consiste no uso da razão ${ }^{8}$, de modo que a urgência da dedicação ao estudo dessa ciência é condição necessária para que o homem possa atualizar ou aperfeiçoar de modo pleno o uso teórico ou contemplativo de sua razão. Com vistas a poder fundamentar essa tese, Aristóteles abre sua investigação dizendo que "todos os homens, por natureza, desejam conhecer". A razão pela qual o estudo dessa ciência pode proporcionar ao homem a realização plena daquilo que determina sua natureza é a primazia absoluta de seu objeto em relação aos objetos pertencentes às demais ciências. $\mathrm{Na}$ medida em que o homem puder se dedicar à contemplação daquilo que é maximamente inteligível em si mesmo, ele atualizará, do modo mais pleno, a função teórica de sua faculdade intelectiva. Pretender-se-á mostrar que a caracterização da ciência buscada como ciência das primeiras causas e princípios, em A 1-2, é a primeira que justifica a eminência absoluta dessa ciência em relação às demais em razão da absoluta superioridade de seu objeto (o segundo passo, o qual confere uma razoabilidade maior à superioridade desse objeto, só é dado em E 1). Assim, a ciência buscada terá determinado o tipo próprio de etiologia que ele é, a saber, a ciência que trata das causas e princípios mais eminentes da realidade em razão de tais princípios pertencerem a objeto(s) primeiro(s).

A construção da filosofia primeira, operada por Aristóteles em sua Metaphysica, inicia em A, caracterizando-a como ciência das primeiras causas e primeiros princípios. Tal caracterização é, nesse primeiro momento, justificada pelo Estagirita mediante a introdução de argumentos que mostram a nobreza do conhecimento científico em geral, a forma hierárquica na qual os tipos de conhecimento científico dispõem-se e como e porque a ciência buscada ocupa o ápice dessa hierarquia, sendo, portanto, a mais nobre de todas as ciências. $\mathrm{O}$ livro A marcará a dimensão etiológica da filosofia primeira que lhe confere caráter de ciência, já que, por definição, todo conhecimento científico é um conhecimento etiológico, cabendo à

\footnotetext{
${ }^{8}$ Ethica Nicomachea I 7 1098a7: "A função do homem é uma atividade da alma acompanhada de razão ou, pelo menos, não sem razão".
} 
ciência tanto descrever seus objetos quanto explicar sua natureza, respondendo, desse modo, o 'que' seus objetos são e 'porque' eles são tal como são, conforme já fora exposto acima. No entanto, tal conhecimento científico do ser difere do das outras ciências em função de tratar-se de um conhecimento científico teórico absolutamente primeiro.

Nesse sentido, Aristóteles apontará as razões que garantirão a preeminência desse seu novo empreendimento: a dignidade do conhecimento científico será provada tendo por base considerações de caráter teleológico concernentes à natureza da função própria do homem. $\mathrm{O}$ Filósofo afirma que o desejo de conhecer é próprio, por natureza, a todo homem, e dá três razões intrinsecamente ligadas para justificar essa afirmação. A primeira razão concerne ao fato que todo ser deseja naturalmente a sua perfeição ou a realização plena do seu ser. Dado que a essência do homem é a animalidade racional, a função intelectiva da alma humana é o elemento que o distingue de todos os outros animais e que o faz ser exatamente o que é. O homem desejará conhecer ao tender à realização plena da sua natureza específica. Para tanto, far-se-á necessário que o homem busque tal atividade, já que o intelecto, sendo somente em potência todas as coisas, torna-se em ato através do conhecimento, pois ele não possui as formas inteligíveis das coisas antes de pensá-las. ${ }^{9}$ A identificação aristotélica entre ato e forma e potência e matéria está na base da explicação dessa tendência natural, pois o intelecto possui a forma inteligível de todas as coisas somente em potência, a qual só pode ser atualizada quando entra em atividade, sendo isto o que ele é por essência. ${ }^{10}$ A segunda razão consiste em todo ser possuir uma tendência natural para a realização de sua função própria e o homem, por sua vez, tenderá naturalmente à sua função própria que é usar a razão e, por conseguinte, inclinar-se-á à busca do conhecimento científico. A terceira razão consiste no fato que todo ser tende naturalmente a estar em conformidade com o princípio que o determina. A racionalidade é a característica distintiva do homem e que o faz buscar, através da atividade intelectiva, conhecer todas as coisas, as quais são princípio e causa da atividade do intelecto. Desse modo, o homem deseja conhecer em função da racionalidade que lhe é imanente e que o determina, a qual, por sua vez, é necessariamente determinada pelas formas inteligíveis presentes nas coisas.

O fato de algum homem não se dedicar ao estudo da ciência primeira ou a qualquer outra ciência particular não refuta a tese que todo homem deseja conhecer e é justamente isso que Aristóteles pretende mostrar quando aduz o exemplo do amor que dispensamos aos

\footnotetext{
${ }^{9}$ De Anima III 4 429a22-24: "Por conseguinte, o assim chamado intelecto da alma (entendo por intelecto isto pelo que a alma pensa e concebe) não é em ato nenhuma coisa antes de pensar".
}

${ }^{10}$ De Anima III 5 430a18. 
sentidos e, em especial, ao sentido da visão. Mesmo que algum homem não se dedique à ciência, ele necessariamente desejará, enquanto animal, outros fins concernentes, pelo menos, às necessidades da vida prática, aos quais só poderá satisfazer quando conhecer as coisas que deseja e os meios para alcançá-las. O conhecimento dessas coisas está vinculado imediatamente à função sensitiva da alma humana, a qual fornece ao homem o primeiro passo em direção ao conhecimento científico propriamente dito, visto que faz o homem perceber as coisas particulares para que, a partir dessa percepção, a função intelectiva da alma possa engendrar conceitos que revelem a quididade dessas coisas. Dentre todos os sentidos, a visão possui uma importância privilegiada pelo fato de ela sofrer a menor alteração material, estando, portanto, mais próxima de ser uma operação propriamente anímica, visto que seu órgão, os olhos, sofre uma afecção fisiológica mais tênue do que o dos outros sentidos, pois a visão, quando percebe o vermelho, por exemplo, não é caso que os olhos fiquem realmente vermelhos como ocorre quando o tato percebe o frio ou o quente, quando a gustação (a qual, para Aristóteles, é um tipo de tato) percebe o doce ou o amargo. Outra razão pode ser dada, ainda, em defesa da superioridade da visão, pois é através dela que podemos perceber diferenças entre as coisas. Tais diferenças concernem à apreensão que a visão opera dos sensíveis comuns como movimento, repouso, figura, tamanho, número e unidade. ${ }^{11}$

Tendo mostrado a preeminência do conhecimento científico em geral, através da afirmação de que todo o homem deseja conhecer, Aristóteles passará, então, a um segundo movimento argumentativo: a explicação da hierarquia do saber. Para tanto, o Filósofo irá estabelecer os níveis de conhecimento concernentes a algumas espécies animais, segundo o grau de complexidade anímica que cada uma delas comporta.

Todo o gênero animal possui o poder da sensação, a qual tem como elemento mínimo o tato, pois, segundo Aristóteles, nenhum animal conseguiria sobreviver sem ele. ${ }^{12}$ Dentre os animais não racionais, há: i) aqueles que são desprovidos de audição e de memória; ii) aqueles que são providos de audição, mas desprovidos de memória e iii) aqueles que são providos de audição e de memória, a qual possui existência tributária da existência da imaginação, visto que a memória consiste no processo de retenção das "re-apresentações" das formas sensíveis dos objetos sem a matéria, sem o concurso de uma percepção atual. Essas representações, por sua vez, são projetadas na alma pela imaginação, através de imagens. O grupo $i$ diz respeito aos animais que não são nem “inteligentes” nem capazes de aprender, isto é, incapazes de

\footnotetext{
${ }^{11}$ De Anima III 1 425a15-16.

${ }^{12}$ De Anima III 13.
} 
serem disciplinados. O grupo $i i$ concerne aos animais que são "inteligentes", mas não capazes de aprender. O grupo iii trata dos animais que são "inteligentes" e capazes de aprender. Essa "inteligência" ou "prudência" dos animais não racionais é apenas um tipo de discriminação sensória que os torna capazes de satisfazer as necessidades para a manutenção de suas vidas e capazes de realizar suas funções próprias. Portanto, os termos "inteligência" e "prudência", quando atribuídos aos animais não racionais, dizem respeito a uma faculdade discriminativa presente neles, cujo grau de perfeição cognitiva é inferior em relação à faculdade cognitiva humana, à intelecção. Assim, essa "cognição" sensória que os animais possuem representa o nível mais baixo na hierarquia do saber.

O texto segue com a análise do saber de que os animais racionais dispõem, o qual também comporta vários níveis, os quais, por sua vez, dispor-se-ão, da mesma maneira que o "conhecimento" dos animais não racionais, hierarquicamente. O homem possui, além de sensação, a qual, segundo Aristóteles, é condição de possibilidade para todo e qualquer tipo de conhecimento ${ }^{13}$, a experiência, a qual pode pertencer aos animais não racionais num grau muito pequeno, mas só existirá própria e plenamente no homem. Essa última surge a partir da associação de muitas memórias de objetos particulares: a forma sensível do objeto recebida pela alma na sensação é re-apresentada à alma (após o desaparecimento do objeto sensível) por uma imagem, a qual, por sua vez, é retida pela memória e, a partir da retenção e repetição dessa imagem, a alma humana associará as várias memórias de um objeto sensível, sintetizando-as e cristalizando-as em uma experiência. Embora a experiência seja um processo associativo pertencente ao poder cogitativo do homem e encontre-se, portanto, em uma posição privilegiada em relação à sensação e à atividade mnemônica dos animais não racionais, ela está relacionada ao que Tomás de Aquino, em seu comentário (§16), chama de "razão particular". Essa "razão" concerne somente à associação de coisas particulares, a partir da qual o homem adquire experiência acerca de alguma coisa tomada somente em sua particularidade, tornando-se capaz, por meio dessa experiência, de agir fácil e corretamente. A "razão universal" ou a razão propriamente dita só far-se-á diretamente ligada à arte, enquanto ela encontra-se sob o registro do conhecimento científico.

A arte, por sua vez, é engendrada a partir da experiência, conforme as palavras de Polo que Aristóteles cita em Metaphysica A 1 981a4-5: "a experiência faz a arte e a inexperiência o acaso". Do mesmo modo como a experiência é engendrada pela memória e a cognição experimental por várias memórias de uma coisa, um juízo universal sobre coisas que são

\footnotetext{
${ }^{13}$ De Anima III 8 432a7-8: "sem a sensação o homem não pode aprender nem compreender nada".
} 
semelhantes entre si provém da apreensão de muitas experiências. Configura-se, dessa maneira, uma hipótese geral formulada a partir de casos análogos, depois de numerosas observações da experiência. Portanto, enquanto a experiência concerne a coisas individuais, a arte concerne à compreensão de coisas universais, visto que a arte é todo conhecimento científico prático baseado em regras gerais e em conhecimentos sólidos, ao contrário da mera experiência. No entanto, cabe ressaltar que, sob o ponto de vista prático, a diferença entre experiência-particular e arte-universal desaparece, visto que toda arte é sempre concebida em função de uma prática e, sob esse aspecto, ambas são operações concernentes a coisas singulares. Aristóteles apresenta, em 981a7-9, um exemplo que esclarece essa afirmação: "Pois, ter a noção que para Cálias, afetado por certa doença, foi bom o uso de certo remédio, e que o mesmo ocorreu com Sócrates e a outros muitos considerados individualmente, é próprio da experiência". Sendo assim, a diferença entre experiência e arte só pode dizer respeito, não ao conhecimento prático, mas sim ao conhecimento teórico. Sob a perspectiva do saber teórico, a arte é eminentemente superior à experiência, pois a experiência revela somente a existência das coisas, mas a arte, enquanto conhecimento, revela as causas, as razões pelas quais as coisas são o que são. Assim, em relação ao exemplo que Aristóteles apresenta, podese dizer que aquele que sabe somente que o remédio que curou Cálias também é capaz de curar Sócrates ou algum outro indivíduo que apresente os mesmos sintomas, tem somente experiência. Enquanto aquele que sabe porque o remédio que curou Cálias também curou Sócrates e pode curar qualquer outro indivíduo que apresente a mesma doença possui a arte medicinal, ou seja, é médico. Portanto, os que possuem arte são mais sábios do que aqueles que só possuem experiência, como, por exemplo, aquele que possui a arte arquitetônica é mais sábio do que os operários que constroem uma casa apenas conhecendo o trabalho manual que deve ser operado para a construção da obra, pois o primeiro conhece as causas presentes na obra, enquanto os últimos conhecem e exercem apenas as operações ligadas à disposição da matéria de que a casa é feita. Um engenheiro naval, além de conhecer a operação do arranjo da madeira, sabe como tal matéria deve ser configurada para que dela venha a ser um navio, conhecendo, portanto, a operação que introduz a forma do navio bem como a finalidade de seu produto. Dentre as causas presentes em um navio, a mais inferior diz respeito à matéria $\mathrm{e}$ a mais elevada concerne ao fim para o qual esse objeto foi construído e é por essa razão que aquele que possui a arte da navegação é superior àquele que possui a arte da construção de navios, pois ao primeiro pertence a realização plena da operação mais nobre do artefato, ou seja, a efetivação plena de sua finalidade. A razão que prova em definitivo a superioridade cognitiva da arte em relação à experiência é o fato da primeira poder ser ensinada e a segunda 
não. O homem que possui apenas experiência conhece as coisas particulares enquanto particulares. Por isso, ele não é capaz de explicar ou ensinar a outrem as causas que revelam o porquê de as coisas se comportarem de um determinado modo e não de outro. Aquele que é meramente experiente acerca, por exemplo, do nexo existente entre a administração de um remédio a um doente e a sua cura, não dispõe do conhecimento causal que explica porque esse remédio curou esse doente e pode, pela mesma razão, curar outros indivíduos que padeçam da mesma enfermidade.

Aristóteles opera, ainda, a distinção entre artes práticas e teóricas a fim de mostrar que as últimas são sabedoria em maior grau do que as primeiras. Enquanto as artes práticas são desenvolvidas visando à satisfação das necessidades da vida prática, as artes teóricas são buscadas como instrumentos úteis a fins concernentes à própria investigação científica.

O próximo passo aristotélico consistirá em apresentar a distinção entre filosofia primeira, ciência e arte. Em Ethica Nicomachea VI 3 1139b 14-15, Aristóteles afirma: "ciência é conhecimento demonstrativo do que é necessário e eterno; a arte é, ao contrário, disposição produtiva acompanhada de razão". Essa distinção entre ciência e arte decorre do fato de a ciência ser produto do uso teórico do intelecto, o qual é responsável pela apreensão dos princípios supremos e das causas primeiras, enquanto a arte e a prudência estão relacionadas ao uso prático da razão.

Após ter afirmado a filosofia primeira como ciência das causas primeiras e dos princípios supremos, caberá, então, precisar quais são essas causas e esses princípios. Para tanto, Aristóteles analisará primeiramente aquilo que caracteriza o conhecimento do sábio para poder extrair, dessa maneira, as características da ciência buscada. O sábio possui o conhecimento dos universais e conhece só em potência os particulares. Portanto, a ciência buscada, assim como qualquer ciência, não pode dizer respeito a causas e princípios presentes nas coisas tomadas particularmente, mas, sim, tomadas universalmente. ${ }^{14}$ Tal ciência deve

\footnotetext{
${ }^{14}$ Nessa passagem de A 2 982a21-23, Aristóteles parece estar querendo chamar a atenção para o fato que a universalidade é a característica distintiva do sábio, não só porque toda ciência é do universal, cf. An. Post. I 4, mas também na medida em que aquele que conhece as coisas do modo mais universal (na medida em que conhece os princípios absolutamente primeiros de todas as coisas e, por isso, os mais universais) possui conhecimento superior em relação àquele que as conhece de modo menos universal. Nesse sentido, salvaguardado o fato de a ciência primeira não ser e não poder ser demonstrativa, Aristóteles afirma em An. Post. I 24 86a21-30: "É evidente que a demonstração universal é mais importante porque, a partir do fato de compreender a primeira das proposições, nós temos como compreender também uma proposição posterior, a qual nós compreendemos potencialmente. Por exemplo, se alguém conhece que todo triângulo tem dois ângulos retos, em algum sentido ele também sabe potencialmente do isósceles que ele tem dois ângulos retos ainda que ele não saiba atualmente que isósceles é um triângulo. Mas aquele que compreende a proposição posterior não conhece o universal em nenhum sentido, nem potencialmente nem atualmente".
} 
tratar das causas e dos princípios mais universais ou primeiros de todas as coisas, revelando a total necessidade de elas serem conforme determinam esses princípios. Tais princípios supremos conferem à filosofia primeira uma superioridade absoluta em relação às demais ciências, pois são os princípios mais fundamentais que se encontram na base da explicação de todas as coisas. A primeira vista, o caráter maximamente universal da filosofia primeira pareceria conduzir de necessidade à aceitação da tese em litígio na primeira aporia, a saber: que há sim uma única ciência que estude todos os tipos de causa. No entanto, ver-se-á logo adiante que os refinamentos e determinações que a "etiologia" do ser enquanto ser sofrerá abrirão caminho para uma resposta à primeira aporia que introduzirá uma qualificação na tese em xeque na medida em que encontrará um modo de unificar, mediante o critério da primazia, os diversos tipos de causalidade ao passo que todos fazem referência à causa formal.

Outro fator que corrobora a afirmação que a filosofia primeira é o conhecimento das causas e dos princípios supremos é que ela, assim como qualquer ciência teórica, não visa a nenhum fim externo e, principalmente, não possui nenhuma finalidade prática. Tal ciência, segundo Aristóteles, é maximamente especulativa e cognoscível, visto que os princípios e as causas primeiros também são, em si mesmos, supremamente cognoscíveis. Dessa forma, Aristóteles aponta que a ciência buscada, a qual é chamada ao longo de todo o livro A de "sabedoria", é almejada por amor ao próprio conhecimento e que, pelo fato de tratar dos princípios e causas absolutamente primeiros, ela é superior a todas as outras ciências.

Após ter determinado que a ciência buscada é a ciência das causas primeiras, Aristóteles passa à determinação (em A 3-10) dos tipos de causas, a saber: i) formal: princípio de determinação que revela aquilo que é ser para uma coisa e a qualifica como algo de certo tipo e não de outro: a causa formal revela a quididade da coisa; ii) material: substrato material a partir do qual a coisa é feita, a qual encontra-se presente em todos os seres sensíveis; iii) eficiente: aquilo a partir do que uma coisa vem a ser; iv) final: aquilo para o que a coisa tende, o fim da coisa. Aristóteles mostra que as causas são apenas essas, nem mais nem menos, a partir da análise crítica da doutrina etiológica dos filósofos que o precederam, os quais, segundo o Estagirita, expuseram tais causas, mas ainda de maneira imprecisa.

Nota-se que mesmo tendo sido estabelecido o âmbito etiológico da ciência buscada, em A 1-2, na medida em que foi mostrada a necessidade de haver uma ciência absolutamente universal que trate das causas e princípios primeiros presentes na realidade, a qual ocupará o ápice da hierarquia das ciências teóricas, é preciso ainda definir qual o objeto próprio à investigação dessa etiologia primeira. E é exatamente essa determinação que tomará lugar quando do estabelecimento da componente ontológica da filosofia primeira em $\Gamma$. 
II 2. O segundo passo da resposta à primeira aporia: a determinação da "etiologia" primeira como ciência das causas primeiras do ser enquanto ser em Metaphysica $\Gamma$

Aristóteles abre $\Gamma 1$ afirmando que "há uma ciência que contempla o ser enquanto ser e o que lhe pertence por ele mesmo" e, dado que ficara acertado em A, que a ciência buscada é ciência das causas e dos princípios primeiros, então, o Filósofo prosseguirá afirmando:

Uma vez que buscamos os princípios e causas mais altas, é evidente que serão necessariamente princípios e causas de certa natureza enquanto tal. (...) Por isso, nós também devemos compreender as primeiras causas do ser enquanto ser. (Г 1 1003a26-28, 31-32).

Assim, a etiologia própria à ciência buscada recebe a primeira determinação do objeto (o ser) em relação ao qual lhe compete investigar as causas e do modo mediante o qual ela o investigará (enquanto ser). Preenchendo assim, um outro requisito necessário à condição de conhecimento científico, a saber, possuir um objeto em relação ao qual cabe a ela determinar as causas. É em $\Gamma$ que pela primeira vez se justifica o porquê da máxima universalidade da filosofia primeira que a faz diferir das ciências particulares: ela não tem por objeto um determinado gênero do ser nem o trata de um modo especializado, sendo universal não só quanto ao domínio, o ser em geral, mas também quanto ao modo de tratar tal domínio na medida em que investiga as causas que explicam a natureza de tudo aquilo que é enquanto é ${ }^{15}$. Nota-se assim, que Aristóteles explica a natureza da filosofia primeira como ciência do ser enquanto ser mediante a comparação por contraste com o comportamento das ciências particulares. Levando-se em conta o caso das outras duas ciências teóricas, a física e a matemática, observa-se que a filosofia primeira comporta-se diferentemente: ao passo que a física investiga o ser enquanto móvel e a matemática o ser enquanto mensurável, recortando, assim, cada uma um gênero do ser sobre o qual suas investigações incidem, a filosofia primeira não recortará um gênero do ser, mas tratará do ser em geral na justa medida em que ele é. E é assim que a componente etiológica recebe sua primeira determinação pela componente ontológica da Metaphysica: a ciência buscada investiga as causas primeiras do ser enquanto ser.

No entanto, a afirmação que a ciência buscada é sabedoria acerca das causas do ser

\footnotetext{
${ }^{15}$ Sobre a peculiaridade do caráter científico da filosofia primeira e sobre a impossibilidade de sua universalidade poder conduzir à defesa da tese que tal ciência consistiria no somatório das ciências particulares, ver Záchia, E. A ciência da Metafisica de Aristóteles. (Dissertação de mestrado - UFRGS, IFCH, Programa de Pós-Graduação em Filosofia, Porto Alegre), 2007, pp. 68-85).
} 
enquanto ser não parece isenta de problemas. Como fazer que o conceito de ser, tomado sem limitação quanto a um gênero, possa figurar como objeto de conhecimento científico? Através do comportamento lógico dos conceitos dos objetos que servem à investigação das ciências particulares, é possível constatar que o comportamento do conceito de ser revela-se nada "seletivo". O bom funcionamento lógico de um conceito qualquer deve permitir que ele identifique o conjunto das coisas as quais ele se aplica bem como o complemento desse conjunto. Ora, o conceito de ser não pode, de necessidade, funcionar dessa maneira, pois ele não consegue identificar uma classe das coisas às quais se aplica em contraposição ao conjunto complemento de tal classe. Uma vez que ele se diz de muitos modos ou, mais exatamente, de tudo aquilo que existe, sem exceção, não há um conjunto complemento das coisas contraposto à classe das coisas a que ele se aplica, pois é sabido, desde Parmênides, que o ser é e o não ser não é. Tendo observado o comportamento bastante "extravagante" do conceito de ser, Aristóteles procurará estabelecer um modo mediante o qual a multiplicidade dos modos como ele é e, por isso, é dito não o torne refratário ao registro científico. Para tanto, é preciso encontrar algum tipo de elemento unificador dentre os diversos modos em que o ser encontra-se disperso. E é justamente com vistas a formular uma base capaz de conferir unidade e estabilidade ao conceito de ser para que ele possa ser objeto de ciência que Aristóteles formulará o expediente da homonímia ${ }^{16}$ por referência a um:

O ser se diz em muitos sentidos, mas em relação a um só princípio. Uns, pois, porque são substâncias, outros porque são afecções da substância, outros porque são caminho até a substância ou corrupções ou privações ou qualidades da substância ou porque produzem ou geram a substância ou as coisas ditas em relação à substância ou porque são negações de alguma dessas coisas ou da substância. ( $Г 2$ 1003b5-10)

Dessa maneira, a etiologia primeira recebe mais uma determinação quanto ao objeto em relação ao qual ele deve investigar as causas: a homonímia por referência a um (que a livra da aporia consequente da multiplicidade dos modos do ser fazendo com que a substância

\footnotetext{
${ }^{16}$ Pode-se identificar em Aristóteles as homonímias por acaso, por semelhança e a do ser. A primeira consiste num fenômeno puramente linguístico, no qual coisas que possuem definições radicalmente distintas têm, contudo, o mesmo nome. A palavra 'banco', por exemplo, é um homônimo por acaso, pois pode designar tanto um artefato que serve de assento quanto uma instituição financeira. A segunda homonímia supracitada refere-se àquelas coisas que são chamadas pelo mesmo nome porque mantêm uma relação de semelhança. Esse tipo de homonímia tem como exemplo a semelhança de um retrato de uma pessoa em relação à pessoa, de um homem morto em relação a um homem, de uma mão decepada em relação a uma mão. A homonímia do ser difere das demais na medida em que ela exige uma ligação lógica necessária entre os diversos modos em que o ser sensível é dito em relação à substância. Tal ligação lógica necessária entre esses diversos termos está fundada na relação de dependência ontológica que as demais categorias possuem com respeito à categoria da substância. Ver essa discussão em Zingano, M. "A homonímia do ser e o projeto metafísico de Aristóteles". (Dissertatio, $\mathrm{n}^{\circ}$. 5, Pelotas, UFPel, 1997), pp. 20-30.
} 
passe a ser o principal modo do ser ao qual todos os demais fazem referência) a conduz a ser a ciência que deve investigar as causas da substância. A relação de dependência logicoontológica dos acidentes em relação à substância é afirmada em $\Gamma 2$, mas é provada tão somente em $\mathrm{Z}$ quando a ontologia far-se-á ousiologia.

\section{3. O terceiro passo da resposta à primeira aporia: a determinação da "etiologia" primeira como ciência das causas primeiras da substância em Metaphysica $Z$}

A prioridade logico-ontológica da categoria da substância em relação aos acidentes é afirmada em razão da substância ser o único dentre todos os modos categoremáticos capaz de preencher o requisito da "separação" e do "ser algo determinado" (Z 3 1029a27-28: "Pois o ser separável e algo determinado parece corresponder sobretudo à substância"). O sentido da separabilidade e da determinação que estão em jogo, em Z, são aqueles que concernem, respectivamente, ao fato que a substância, para existir, não depende da existência de nenhuma outra coisa a não ser ela mesma (ao contrário do que ocorre aos acidentes, os quais só podem existir na medida em que existem na substância) e à permanência da identidade da substância sensível no que se refere àquilo que lhe determina essencialmente, malgrado a indeterminação a qual ela está exposta devido à fraqueza ontológica dos acidentes que nela inerem.

Nesse sentido, caberá à etiologia primeira investigar e determinar as causas primeiras da substância. E parece que é justamente procurando responder o que é causa e princípio primeiros da substância que Aristóteles elegerá a forma como princípio de substancialidade, em mais alto grau, da substância composta. Nesse sentido, Aristóteles afirma, em Z 3 1029a57: "se a forma é anterior à matéria e mais ser que ela, pela mesma razão, será também anterior ao composto de ambas" e, em 1029a27-32:

Parece, pois, corresponder sobretudo à substância o ser separável e algo determinado; por isso, a forma e o composto de ambas parecem ser substância, em mais alto grau, do que a matéria. Mas omitamos a substância composta de ambas, a saber, a que se compõe de matéria e forma, pois é posterior e clara.

Assim, a forma será considerada princípio de substancialidade, em mais alto grau, da substância composta na medida em ela responderá pelo princípio de determinação da substância. Uma vez que a matéria é da ordem do relativo, sendo algo de determinado tão somente na medida em que mantém relação com a forma, a forma será responsável pelo princípio de identidade da substância, o princípio especificador que torna possível responder o que é precisamente ser para cada uma das substâncias compostas. Assim, é claro que, na medida em que o composto é dotado de matéria, ele é menos apto a responder, enquanto tal, 
por aquilo que é princípio e causa de ele ser exatamente o que é, por ser causa da sua de determinação. Por mais que o vocábulo 'causa' não possa ser considerado recorrente no livro Z, parece ser inegável que, ao afirmar que a substância é forma, Aristóteles está respondendo pela causa primeira que faz a substância ser exatamente o que ela é. Nessa justa medida, é absolutamente compreensível a volta vigorosa do vocabulário etiológico no capítulo que encerra Z:

É, pois, evidente que se busca a causa; e esta é, do ponto de vista dos enunciados, a essência, a qual é em algumas coisas a causa final, por exemplo, sem dúvida numa casa ou numa cama e noutras o primeiro motor; pois também isso é uma causa. Mas esta última a buscamos quando se trata da geração e corrupção; a outra, ao contrário, quando se trata do ser. (...) E, uma vez que é preciso saber que a coisa existe, é evidente que se pergunta por que a matéria é algo determinado (...). Portanto, se busca a causa pela qual a matéria é algo (e esta causa é a forma); e esta causa é a substância. (Z 17 1041a27-32)

Dessa maneira, a etiologia primeira tratará universalmente dos tipos causalidade presentes na realidade na medida em que tratar dos mais importantes dentre eles. A matéria fora excluída da corrida pelo título de causalidade primeira desde a discussão da primeira aporia em B 2. Ao longo de Z, a causa formal parece ter conquistado tal título, mas é preciso qualificar tal afirmação no que diz respeito à natureza das substâncias sensíveis sublunares, pois, nesse caso, causa formal, final e eficiente se identificam. Respondendo que a causa primeira da substância é aquela que lhe confere o maior grau de determinação na medida em que responde essencialmente o que ela, a ciência primeira abrirá caminho para o estabelecimento de uma substância cujo ser não comporta causalidades de tipo secundário, de um ser que será pura forma. E é assim que a etiologia primeira far-se-á teologia.

II 4. O quarto passo da resposta à primeira aporia: a determinação da "etiologia" primeira como ciência que investiga como a substância absolutamente primeira é causa da realidade em Metaphysica $E 1$ e $\Lambda 6$

A caracterização prévia da etiologia primeira, em A 2, como ciência que trata dos princípios e causas absolutamente primeiros em razão de tratar de objetos cuja natureza é maximamente cognoscível porque maximamente determinada, sugere que Aristóteles pretende garantir a primazia da filosofia primeira não só em virtude da sua universalidade irrestrita, mas por acreditar que ela só pode preencher o requisito da primazia se tratar de substâncias de outra ordem do que aquelas que a filosofia segunda trata. É com vistas a avançar na determinação do caráter primeiro da ciência buscada que Aristóteles pretende 
completar o projeto da sua Metaphysica em E 1. Vejamos, então, como se dá a realização dessa tarefa.

E 1 opera, em primeiro lugar, a caracterização da filosofia primeira mediante o contraste da sua natureza em relação a da ciências particulares; em segundo lugar, tal contraste é deslocado para o interior das ciências teóricas; em terceiro lugar, a universalidade da ciência buscada passa a ser derivada da sua primazia dentro da articulação conceitual entre 'primeiro' e 'universal' que serve à passagem da ousiologia à teologia operada no final de E 1. A primeira tarefa de E 1 é realizada mediante a retomada explícita da caracterização da ciência buscada como etiologia primeira e da determinação da natureza dessa etiologia, em $\Gamma$, como ciência dos princípios e causas do ser enquanto ser. Nesse sentido, a filosofia primeira, para poder ser considerada conhecimento científico, assim como qualquer outro, deverá ser ciência dos primeiros princípios e causas sem, no entanto, que quaisquer ciências particulares possam ser ditas 'ciência' do mesmo modo que ela devido à máxima universalidade que caracteriza seu objeto (todos os seres) e o seu modo de investigá-lo (enquanto seres). Além da ciência buscada se diferenciar das etiologias particulares pelo fato de não tratar apenas de um gênero do ser, mas do ser na sua totalidade, ela também se difere delas pelo fato de ser a única ciência que prova a existência de seus objetos, ao contrário do que ocorre às ciências particulares que ou bem os admitem por hipótese (como é o caso da matemática) ou via experiência (como é o caso da física).

A argumentação de E 1 segue com a distinção entre as virtudes do intelecto, as quais podem ser práticas (ética e política), produtivas (as engenharias, medicina, etc.) e teóricas (filosofia primeira, filosofia segunda e matemática). Tal distinção tem por fim último poder produzir o enlace conceitual entre as noções de 'primeira' e 'universal', no caso da filosofia primeira, a partir da comparação entre os objetos das ciências teóricas. O princípio que guia a distinção aristotélica dos diversos tipos de saberes é a natureza do objeto ${ }^{17}$, assim, um conhecimento será dito prático, produtivo ou teórico de acordo com o caráter intrínseco ou extrínseco do princípio que move tais objetos. Nesse sentido, a física ou filosofia segunda é uma ciência teórica em razão de seu objeto possuir princípio interno de movimento (e repouso) em si mesmo e pode ser dito 'separado' na medida em que não depende da existência de nenhuma outra para existir, no entanto, nenhum dos dois princípios que o

\footnotetext{
${ }^{17}$ Se é verdade que o princípio norteador da divisão dos saberes, segundo Aristóteles, é a natureza do objeto, então, parece, à primeira vista, que será problemático compreender em que sentido "a filosofia prática, ou ciência política, não obstante sua intenção prática, é uma virtude da razão teórica, pelo fato de ser sempre uma ciência", conforme aponta Berti, E. As razões de Aristóteles. (São Paulo, Loyola, 2002), p. 145.
} 
compõe pode existir separadamente um do outro, a saber, a forma e a matéria das coisas sensíveis não podem existir ontologicamente separadas uma da outra. Já as virtudes do intelecto serão ditas práticas ou produtivas quando seus objetos, as ações éticas, as ações políticas e os artefatos possuírem princípios de movimento que lhes são externos ${ }^{18}$, a saber, respectivamente, o agente moral, o cidadão e o artífice. As virtudes práticas se distinguem ainda das produtivas em razão do fim das últimas ser algo extrínseco e ontologicamente separado da própria atividade do agente produtor, a saber, os artefatos, enquanto, as ações morais e políticas refletem e incidem sobre o próprio agente moral e político sem ter como fim algo que lhe seja externo e ontologicamente separado. Já a matemática é dita uma virtude teórica do intelecto porque seus objetos são tratados pelos matemáticos como se fossem imóveis e separados. Aristóteles afirma que não resolverá, em E 1, se eles são ou não imóveis e separados, pois o importante, por agora, é que os matemáticos os tratam enquanto tais, contudo, ele adiantará (1026a14-15) que eles são com certeza imóveis, mas de modo nenhum ontologicamente separados. Será somente nos livros M e N que Aristóteles resolverá essa questão (e também aquela suscitada pela aporia 12) dizendo que as entidades matemáticas não comportam qualquer tipo de separação ontológica, visto que só são na medida em são propriedades das coisas extensas.

A argumentação de E 1 prossegue afirmando que se há algum objeto eterno, imóvel e (absolutamente) separado, evidentemente seu estudo pertencerá a uma ciência teórica em razão da caracterização das virtudes teóricas do intelecto, no entanto, não poderá ser o caso que o trate a física (visto que ele trata das substâncias móveis) nem a matemática (visto que seus objetos são imóveis mas não separados da matéria). Sendo assim, só caberá a ciência especulativa anterior a ambas tratá-lo, a saber, a filosofia primeira. A argumentação de E 1 prossegue: "a primeira ciência trata de objetos separados e imóveis. Todas as causas são eternas e, sobretudo, estas, pois são as causas dos seres divinos que nos são manifestos" (1026a16-18).

A conclusão desse passo argumentativo de E 1 é que haverá, então, três ciências teóricas: a matemática, a física e a teologia. Se há um tal tipo de natureza divina, ela só poderá

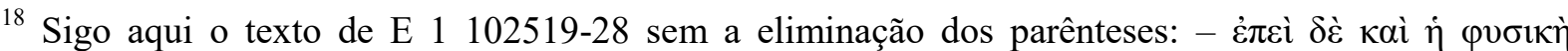

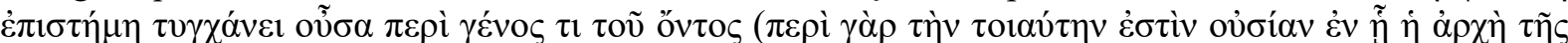

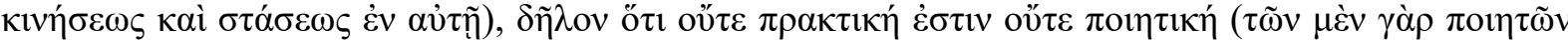

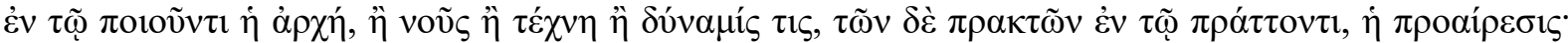

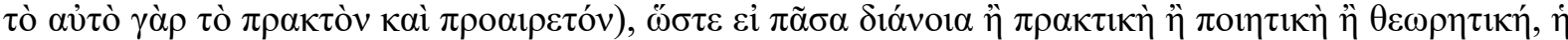

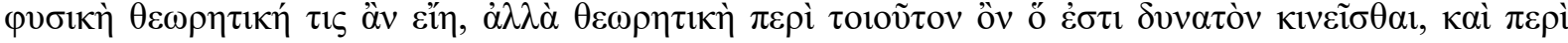

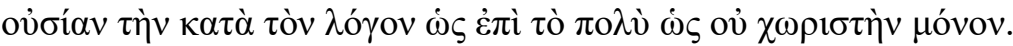


ser tratada pela ciência mais elevada, pois é necessário que aquilo que é mais elevado seja investigado pela mais nobre dentre as ciências especulativas e, nesse caso, será a teologia. Vêse, então, como a etiologia primeira, a qual progredira em sua determinação como ciência dos princípios e causas do ser enquanto ser (ontologia) e da substância (ousiologia) passar a ser ciência dos princípios e causas da(s) substância(s) divina(s) ou absolutamente primeira(s). Dada a universalidade irrestrita da ciência buscada era- se de esperar que, caso houvesse uma substância de outra natureza do que as sensíveis, tal como fora visto a propósito da apresentação da resposta à quinta aporia, ela deveria tratá-la sob pena de deixar de preencher o requisito de cientificidade em questão, a saber, a universalidade irrestrita quanto ao seu domínio investigativo. Se é assim, então a filosofia primeira é teologia porque deve tratar de todas as substâncias. No entanto, Aristóteles opera uma inversão na ordem da relação de fundamentação entre os conceitos de 'universal' e 'primeira' na última passagem de E 1 (1026a27-32). Relembremo-nos dela:

Se não há nenhuma outra substância do que aquelas pelas quais a natureza é formada, a física será a ciência primeira; mas, se há alguma substância imóvel, a ciência dessa substância deverá ser anterior e filosofia primeira, e universal precisamente por ser primeira; e a esta cabe considerar o ser enquanto ser, o que ele é e os atributos que lhe pertencem enquanto ser.

Ora, era possível bem compreender que a ciência buscada devia tratar da substância absolutamente primeira na medida em que devia investigar todas as substâncias e, nessa medida, ela seria ciência primeira porque universal. Como compreender, então, que seu caráter primeiro não seja mais derivado ou fundado em sua universalidade, mas, sim, que o contrário se dê? Como compreender que, em razão de tratar de uma substância em particular, a substância divina, a ciência buscada seja universal? Eis então o conflito aparentemente insolúvel entre a perspectiva teológica da ciência buscada e as demais. Se há uma maneira de dissolver tal conflito, isso só poderá ocorrer mediante o esclarecimento do modo como os conceitos de primazia e universalidade operam dentro da dimensão teológica.

A noção de universalidade operou, tanto em A 1-2 quanto em $\Gamma$ 1-2, como característica mais importante do conhecimento científico buscado, a qual o texto aristotélico empenhou-se em esclarecer mediante a introdução das perspectivas ontológicas e ousiológicas enquanto estas elucidavam a que tipo de universalidade o conceito de ser, bem como seus princípios e causas, se prestavam: era sempre como vistas a mostrar que, investigando o ser enquanto ser e seu modo principal, a substância, estar-se-ia investigando todas as coisas. Cabe agora, compreender, sob pena de tornar a passagem da ousiologia à teologia uma marca da inconsistência do projeto metafísico de Aristóteles, como pode ocorrer a subordinação da 
noção de universalidade em relação à de primazia sem que ela se seja posta em risco. Fora visto, pela análise da fórmula reduplicativa "ser enquanto ser" e do dispositivo da homonímia por referência a um, que o fato da ciência buscada tratar dos princípios e causas da substância lhe permite tratar de todos os seres na medida em que todos fazem referência ao principal modo dentre eles, a substância. Não parece lícito querer encontrar uma simetria na relação de dependência entre os pares conceituais substância-acidente e substância simples - substância composta, pois não parece, de modo algum, que seja o caso que a substância sensível tenha de fazer referência a alguma outra coisa do que ela mesma para ser o que é. Assim sendo, parece vedada a tentativa de atribuir uma homonímia por referência a um ao segundo par conceitual cujo sentido focal seria a substância divina. Nesse sentido, parece ser rejeitável uma interpretação tal como aquela adota por Owens, J. The doctrine of being in the aristotelian Metaphysics. (Toronto, Pontifical Institute of Medieval Studies), 1978, o qual antecipando o caráter de causalidade final que o primeiro motor imóvel terá, pretende defender uma relação de homonímia por referência a um dentre os diversos sentidos em que o termo ' causa' é dito, remetendo-os à causa final como o principal modo da causalidade:

A causalidade final deve ser mostrada como a base da referência pròs hen do Ser em todas as outras coisas. A causalidade final dá origem a todas as outras coisas. (...) Assim como a 'saúde', estudada em todas as instâncias do 'saudável', é a saúde do organismo corporal, assim o Ser, estudado em algo [que é] de modo absoluto, é o Ser das Entidades divinas e separadas”. (Owens, 1978, pp.300 e 298)

Foge aos nossos objetivos aqui decidir se Owens tem algum amparo textual para afirmar a existência de uma homonímia por referência a um entre os diversos modos em que o termo 'causa' é dito e tomar a causa final como o sentido focal dentre eles. A única coisa que parece segura é que, mesmo que ele pudesse fazê-lo, disso não se seguiria aquilo que figura como conclusão em seu supracitado argumento, a saber, que o primeiro motor imóvel é causa final (sem qualificação) de todas as coisas. Ora, para cada uma das coisas que fazem parte da mobília da realidade, há uma causa final que é diretamente identificável no interior do processo que visa a cumprir a consecução de tal fim (conforme fora visto no início da exposição deste segundo capítulo a propósito das bases teleológicas da doutrina aristotélica). Parece ser só sob um certo aspecto (mas essencial, é verdade) e indiretamente que o primeiro motor é causa final de todas as substâncias, conforme ver-se-á a seguir. Também parece insuficiente apelar para o fato que a primazia da teologia se justifica na medida em que a natureza da substância divina é primeira em razão de ser absolutamente determinada (o que será justificado em $\Lambda$ quando ela será caracterizada como simples e ato puro) e, portanto, substância em sentido melhor e, por isso mesmo, primeiro em relação às substâncias 
sensíveis. Contudo, isso ainda não explica porque, ao tratar dessa substância melhor e primeira, ela trataria de tudo, isto é, seria universal.

A única estratégia que parece dissolver tal tensão é tentar mostrar que a substância divina explica universalmente a natureza de todas as coisas, sendo, então, em algum sentido, princípio e causa de todas elas. A substância absolutamente primeira parece explicar universalmente, em última instância, um aspecto essencial a todas as substâncias sublunares, a saber, enquanto ela é causa final da eternidade do movimento do universo. O que vale ressaltar é que Aristóteles parece ter acreditado ser lícito inverter a relação de fundamentação entre os conceitos de 'primeira' e 'universal' no âmbito da passagem da ousiologia para a teologia porque o estudo dessa substância em particular fornece a elucidação de um princípio e causa que explica universalmente a natureza de todas as substâncias, mantendo intacto o caráter maximamente universal da filosofia primeira. A interpretação de Augustin Mansion parece ser a que melhor sugere que se deva interpretar a passagem da ousiologia à teologia dessa maneira:

$\mathrm{O}$ apêndice que fecha $\mathrm{E} 1$ tem precisamente por objetivo mostrar que a filosofia primeira, tendo por objeto a substância imutável ou Deus, é, contudo, uma ciência universal, isto é, se estende a todo ser e estuda o ser enquanto tal. Mas o simples fato de Aristóteles suscitar a questão e crer dever provar, ainda que brevemente, a consistência de sua resposta mostra que há ao menos uma nuance que separa sua concepção de filosofia primeira da de ciência do ser enquanto tal, ainda que elas sejam inseparáveis e, em certa medida, coincidam. (...) Mas as breves indicações de Aristóteles, no final de E 1 , visam precisamente a mostrar que, sem um conhecimento do Ser primeiro, o conhecimento de todo o ser permanece incompleto: assim, a filosofia primeira deverá ser integrada à ciência do ser enquanto tal, da qual ela formará, de algum modo, o fecho da abóbada. Pois não se pode mais pôr em dúvida que, aos olhos de Aristóteles, este Ser primeiro imutável possui a função de princípio ou causa face a todos os outros seres. ${ }^{19}$

Parece que, em $\Lambda$, Aristóteles tornará afirmativa a supracitada proposição condicional enunciada do final de E 1 1026a27-32. Lemos em $\Lambda 1$ 1069a30-b2:

Há três tipos de substâncias. Uma é a sensível, a qual se divide em eterna e corruptível. Esta é admitida por todos, por exemplo, as plantas e os animais. Aquela é a eterna, cujos elementos é necessário investigar se são um ou vários. A terceira é imóvel e dela, dizem alguns que é separável; e uns a dividem em dois tipos, enquanto que outros incluem numa mesma natureza as formas e as coisas matemáticas e outros só admitem as coisas matemáticas. As duas primeiras pertencem ao domínio da física (pois implicam movimento); mas à terceira corresponde a outra ciência, se não há princípio comum a todas elas.

Aristóteles parece responder à questão, enunciada em B 1, se são um ou vários os gêneros da substância da seguinte maneira: eles são dois, sensível e imóvel, sendo que o

\footnotetext{
${ }^{19}$ Mansion, A. "Filosofia primeira, filosofia segunda e metafísica em Aristóteles. In: Zingano, M. (Org.): Sobre a Metafísica de Aristóteles. (São Paulo, Odysseus), 2005, p.135.
} 
primeiro gênero subdivide-se em duas classes: substâncias sensíveis corruptíveis e substâncias sensíveis eternas e o segundo não comporta subclasses (conforme. também $\Lambda 6$ 1071b3-5). Assim, Aristóteles se afastará da resposta platônica que subdivide o gênero da substância imóvel em dois: as formas e os seres matemáticos intermediários. Para construir sua própria resposta, Aristóteles necessita fazer a recapitulação (em $\Lambda$ 1-5) de como o movimento ocorre em relação às substâncias sensíveis corruptíveis para, a partir disso, mostrar o porquê da necessidade da postulação de substâncias sensíveis eternas e da substância imóvel. Para firmar a necessidade da existência de substâncias eternas, Aristóteles apresenta o seguinte argumento, em $\Lambda 6$ 1071b5-10: se não existissem substâncias não corruptíveis, então, então todas as coisas seriam corruptíveis (uma vez que todos os modos categoriais em que o ser sensível encontra-se disperso dependem da existência da substância para existirem); É impossível que isso seja verdade pois há pelo menos duas coisas, o movimento e o tempo, o qual é uma propriedade do movimento, que não foram geradas nem virão a se corromper; Logo, deve haver substâncias não corruptíveis que sejam capazes de explicar a eternidade de ambos, a qual é observável pela sucessão ininterrupta de gerações e corrupções de diferentes substâncias, as quais são todas corruptíveis.

A premissa do argumento supracitado, "é impossível que o movimento e o tempo tenham sido gerados ou venham a se corromper", é somente citada em $\Lambda$. A prova do caráter perene do movimento e do tempo ocorre em Physica VIII 1-327. Em relação ao caráter perene do movimento, resumidamente, o argumento (redução ao absurdo da tese que o movimento possa ter vindo a ser ou possa deixar de ser) da Physica seria o seguinte: suponha que o movimento tenha vindo a ser. Para que tal movimento tenha vindo a ser é necessário supor um movimento anterior que seja causa dele ter vindo a ser, pois do nada, nada vem. Ora, se todo movimento precisa de um movimento anterior que seja a causa de seu vir a ser, então não pode haver um movimento que possa ser considerado primeiro. Logo, o movimento não pode ter sido gerado. A pressuposição que faz a redução ao absurdo funcionar parece ser que o processo de geração é, por definição, um movimento e que todo movimento, para vir a ser, precisa de outro que lhe seja causa (pois do nada, nada vem). Tendo isso em vista, caso alguém quisesse afirmar que o movimento tenha sido gerado, então seria forçoso aceitar a tese contraditória que deve haver um movimento (a causa do vir a ser do movimento) antes que haja movimento (antes do movimento ser gerado). Assim, o movimento sempre foi sem nunca ter sido gerado. Os argumentos que provam a impossibilidade da geração do movimento valem também para a impossibilidade da corrupção do movimento: do mesmo modo como a suposição de um primeiro movimento implica a contradição de haver um movimento anterior 
ao primeiro movimento, a suposição da corrupção do movimento também implica a contradição de haver um movimento posterior ao "último" movimento. Dado que a corrupção também é, por definição, um tipo de movimento, é forçoso admitir, para todo processo de corrupção, uma causa capaz de ter originado tal processo. Caso se admitisse um movimento de corrupção que pudesse ser considerado o último, dever-se-ia supor que o agente motor da destruição se corrompesse ao mesmo tempo em que aquilo que sofre corrupção mediante sua agência, o que é absurdo, pois aquilo que não é não pode causar a corrupção (conforme a suposição supracitada que do nada, nada vem). Uma vez que o processo de corrupção deve ter uma causa que lhe anteceda, ela não pode deixar de existir ao mesmo tempo em que aquilo que sofre a corrupção, assim como, por exemplo, o deixar de ser queimado (em ato) não implica a destruição da potência de ser queimado, cabendo a tal causa potencial vir a ser destruída depois do "último" movimento de corrupção, o que é contraditório.

Em relação ao caráter perene do tempo ${ }^{20}$, o argumento (redução ao absurdo da tese que o tempo foi gerado ou é corruptível) parece ser, em linhas gerais, o seguinte: suponha que o tempo tenha sido gerado. Sendo assim, será forçoso admitir que há um momento anterior (no tempo) em que o tempo não existia. No entanto, a pressuposição de um momento anterior já implica a existência do tempo. Do mesmo modo, caso fosse suposto um momento do tempo que pudesse ser considerado o último, então ter-se-ia de supor a existência de um momento (do tempo) em que o tempo não fosse, o que também é absurdo.

Nesse sentido, Aristóteles pretende sustentar a tese da necessidade absoluta da existência de um primeiro motor imóvel em razão do movimento do primeiro céu (das estrelas fixas), o qual é, conforme a observação empírica atesta, contínuo e eterno, não poder ser operado por si mesmo, uma vez que tudo o que se move é movido por outro ${ }^{21}$ e, sendo assim, deve haver um movente desse primeiro céu movido que seja necessariamente imóvel, pois, do contrário, regressar-se-ia ao infinito na cadeia do "ser movido por". Aristóteles pretende esclarecer como tal motor move o céu das estrelas fixas sendo ele próprio imóvel através de dois exemplos de coisas que são causa do movimento sem serem eles próprios movidos, a saber, o bem e o inteligível: o objeto de desejo e o inteligível movem nossas faculdades desiderativas e intelectivas sem serem movidos por elas ou por qualquer outra coisa.

Assim sendo, parece que Aristóteles bem fundou as relações entre os conceitos de universalidade e primazia que caracterizam a ciência buscada desde os primeiros até os

\footnotetext{
${ }^{20}$ Para tal argumentação em prol do caráter perene do movimento e do tempo, ver especialmente Physica VIII 1 251b10-252b5.

${ }^{21}$ Conforme Physica VII 5.
} 
últimos esforços em direção à determinação da sua natureza. Todas as determinações pelas quais a ciência buscada passou parecem ser condições sine qua non para que a ciência buscada pudesse cumprir o conceito mesmo de conhecimento científico em questão, a saber, ciências dos princípios e causas absolutamente primeiros do ser, do ser enquanto ser, da substância e da substância absolutamente primeira e como, esta última, é princípio e causa explicativos de toda a realidade. Assim, não vemos como poderia ser legítimo afirmar que, para cumprir seu projeto metafísico, Aristóteles poderia deixar de cumprir alguma dessas etapas e, ainda assim, não desmantelar a consistência mesma ou a intensão de seu conceito de filosofia primeira. Nesse sentido, não parece lícito pretender relegar as aporias concernentes às questões acerca da possibilidade de substâncias de ordem não sensível a uma fase imatura do pensamento metafísico de Aristóteles, pois é inegável, não só pelo esforço empreendido por A 1-2, Г 1-2 e E 1, o qual acabamos de acompanhar, em elucidar como a ciência é primeira e universal na medida em que é ciência dos princípios e causas supracitados, mas também pelo esforço empreendido em $\mathrm{Z}, \mathrm{H}$ e $\Theta$ em elucidar que aquilo que responde, em mais alto grau pelo princípio e causa da substancialidade das coisas sensíveis, a saber, a forma, o ato, o fim (e o bem), abrirão caminho, de necessidade, pelo menos segundo os olhos de Aristóteles, à postulação de uma substância absolutamente primeira na medida em que é simples, pura forma, puro ato e explicação última da causalidade final da eternidade do movimento do universo. Parece ser exatamente nesse sentido, então, que a "etiologia primeira" vai sofrendo determinações, ao longo do desenvolvimento do projeto da Metaphysica, ao se desdobrar em ontologia, ousiologia e teologia, na justa medida em que é mostrado o modo como ela é uma e mesma ciência que trata universalmente dos princípios e causas de todas as substâncias e como é necessário que haja, para garantir seu caráter anterior em relação às outras ciências teóricas, uma substância divina que seja princípio e causa de toda a realidade. De modo que cada uma das perspectivas em que a ciência buscada se desdobra é, tomada isoladamente, condição necessária para que ela possa satisfazer a intensão o conceito de conhecimento científico em questão, mas somente tomadas conjuntamente e como necessariamente interligadas é que são satisfeitas as condições suficientes à satisfação desse conceito.

Dada a unidade dos conceitos que perpassam o projeto da Metaphysica, parece ser possível defender que Beta pode ser considerado, de uma forma bastante qualificada, um programa para ciência que Aristóteles desenvolve nos demais livros ou, pelos menos, na maioria deles. Tal maneira com que Beta pode ser considerado um programa ou itinerário a ser cumprido pela investigação metafísica consiste no fato das discussões das aporias girarem 
sempre em torno de um pequeno número de conceitos, a saber, 'princípio', 'causa' e 'substância' e desses conceitos serem os princípios fundadores da ciência metafísica, conforme fora visto em razão das determinações que a etiologia primeira recebera ao transformar-se em ontologia, ousiologia e teologia. Defendemos alhures ${ }^{22}$ que as aporias de B tratam desses conceitos de um duplo modo, a saber, i) enquanto as mais radicais (1-5) impedem a possibilidade do estabelecimento da ciência buscada na medida em que, se não se der uma determinada resposta a elas, a ciência buscada não consegue satisfazer o conceito de conhecimento científico em questão, isto é, não consegue firmar a consistência da sua intensão; ii) enquanto as secundárias (6-15), ao contrário das ditas "radicais", não impossibilitam o seu estabelecimento, mas, antes, pressupondo que tal ciência seja possível, perguntam, então, por aquilo que, no mundo, pode ser subsumido aos conceitos que o estabelecimento da consistência da sua extensão mostrou que ela envolve, ou seja, o que no mundo pode preencher materialmente o conceito de "substância" e de " princípios e causas da substância". Eis o sentido no qual julgamos que Beta pode ser tomado como um programa para a ciência buscada e desenvolvida em grande parte dos demais livros que compõem o tratado da Metaphysica, uma vez que todas as discussões internas a Beta estão às voltas de um mesmo núcleo duro de conceitos, os quais operam como fundadores do projeto da ciência buscada e também são encontrados ao longo de toda a obra.

Marina dos Santos

Universidade Federal de Santa Catarina

\section{Bibliografia}

Alexandre de Afrodísia. On Aristotle Metaphysics 1. [Translated by W. E. Dooley]. London, Duckworth, 1989.

Alexandre de Afrodísia. On Aristotle Metaphysics 2 \& 3. [Translated by W. E. Dooley \& A. Madigan]. London, Duckworth, 1992.

Alexandre de Afrodísia. On Aristotle Metaphysics 4. [Translated by A. Madigan]. London,

${ }^{22}$ Santos, M. (2006, pp. 13-14, 38-42, 120). 
Duckworth, 1993.

Alexandre de Afrodísia. On Aristotle Metaphysics 5. [Translated by W. E. Dooley]. London, Duckworth, 1994.

Aristóteles. De Anima. [Translated by R. D. Hicks]. New York, Prometheus Books, 1991.

Aristóteles. Generation of animals. [Translated by A. Platt]. Complete Works of Aristotle , Vol. I. Jonathan Barnes (ed.). Princeton University Press, 1995, p.1111- 1218.

Aristóteles. La Métaphysique. [Traduction et commentaire par J. Tricot]. 2 tomes. Paris, Vrin, 2003.

Aristóteles. Metafisica. [Edición trilingüe por Valentín García Yebra]. Madrid, Gredos, 1998.

Aristóteles. Metaphysics - Book $\Theta$. [Translated with a commentary by Sthephen Makin]. Clarendon Aristotle series, Oxford, Claredon Press, 2006.

Aristóteles. Metaphysics - Books B and K 1-2. [Translated with a commentary by Arthur Madigan]. Clarendon Aristotle series, Oxford, Claredon Press, 1999.

Aristóteles. Metaphysics - Books $\Gamma, \Delta, E$. [Translated with a commentary by Christopher Kirwan]. Clarendon Aristotle series, Oxford, Claredon Press, 1980.

Aristóteles. Metaphysics. [A revised text with introduction and commentary by W. D. Ross]. 2 Vol., Oxford University Press, 1997.

Aristóteles. Nicomachean Ethics. [Translated by W. D. Ross]. Complete Works of Aristotle, Vol. II. Jonathan Barnes (ed.). Princeton University Press, 1995, p. 1729- 1867.

Aristóteles. On the Heavens. [Translated by J. L. Stocks]. Complete Works of Aristotle, Vol. I. Jonathan Barnes (ed.). Princeton University Press, 1995, p. 447-511.

Aristóteles. Physics. [Translated by R. P. Hardie \& R. K. Gaye]. Complete Works of Aristotle, Vol. I. Jonathan Barnes (ed.). Princeton University Press, 1995, p. 314-446.

Aristóteles. Posterior Analytics. [Translated by Jonathan Barnes]. Complete Works of Aristotle, Vol. I. Jonathan Barnes (ed.). Princeton University Press, 1995, p. 115- 166.

Barnes, J. “Metafísica”. In Barnes, J. (ed.): Aristóteles. São Paulo, Ideias e Letras. 2009, pp. 103-154.

Berti, E. As razões de Aristóteles. São Paulo, Loyola, 2002.

Crubelier, M. “Aporiai 1-2", In: Crubelier, M. \& Laks, A. (ed.). Aristotle's Metaphysics Beta. Symposium Aristotelicum. Oxford University Press, 2009, pp. 47- 72.

Jaeger, W. Aristóteles - bases para la historia de su desarrollo intelectual. México, Fondo de cultura económica, 1995.

Mansion, A. Filosofia primeira, filosofia segunda e metafísica em Aristóteles. In: Zingano, M. (Org.): Sobre a Metafísica de Aristóteles. São Paulo, Odysseus, 2005, p. 123-176.

Owens, J. The doctrine of being in the aristotelian Metaphysics. Toronto, Pontifical Institute of Medieval Studies, 1978.

Pereira, O. P. Ciência e dialética em Aristóteles, São Paulo, UNESP, 2000.

Santos, M. A unidade da Metafísica de Aristóteles a partir das aporias do Livro Beta. Tese de Doutorado, UFRGS, IFCH, Programa de Pós-Graduação em Filosofia. Porto Alegre, 2011.

Santos, M. As aporias do livro B da Metafísica de Aristóteles. Dissertação de Mestrado, UFRGS, IFCH, Programa de Pós-Graduação em Filosofia. Porto Alegre, 2006.

Tomás de Aquino. Commentary on Aristotle's Physics. [Translated by R. J. Blackwell, R. J. Spath, W. E. Thirlkel]. Indiana, Dumb Ox, 1995.

Tomás de Aquino. Commentary on the Metaphysics of Aristotle . [Translated by J. Rowan]. Chicago, Henry Regnery Company, 1961. 
Tomás de Aquino. Exposition of Aristotle's treatise On the Heavens. [Translated by R. F. Larcher and P. H. Conway]. Ohio, College of St. Mary of the Springs Columbus 19, 1964.

Záchia, E. I. A ciência da Metafisica de Aristóteles. Dissertação de mestrado - UFRGS, IFCH, Programa de Pós-Graduação em Filosofia. Porto Alegre, 2007.

Zingano, M. A homonímia do ser e o projeto metafísico de Aristóteles. Dissertatio, $\mathrm{n}^{\circ}$. 5, Pelotas, UFPel, 1997, p. 5-31. 